\title{
Mickey Mouse con moño
}

\section{Mickey Mouse with bowtie}

\section{$\begin{array}{lll}\text { M. F. Sisu Di Pizio } & \text { P. S. Sauré } & \text { E. Mayor }\end{array}$ \\ 1 Servicio de Diagnóstico por Imágenes, Hospital San Martín, La Plata, Argentina}

Rev Argent Radiol 2018;82:52.

La magia de Disney llega a lugares insospechados. En este caso al mesencéfalo, donde aparece una conformación que simula la cara de Mickey Mouse con un mõno en su cuello. En un plano axial de resonancia magnética, ponderado en $\mathrm{T} 1$, se
Address for correspondence M. F. Sisu Di Pizio, Servicio de Diagnóstico por Imágenes, Hospital San Martín, La Plata, Argentina (e-mail: mfsisu@hotmail.com).

percibe la cara del ratón, conformada por los pedúnculos cerebrales como las orejas, los núcleos rojos como los ojos, el acueducto de Silvio como la boca y los tubérculos cuadrigéminos como el mõno en su cuello (-Fig. 1).

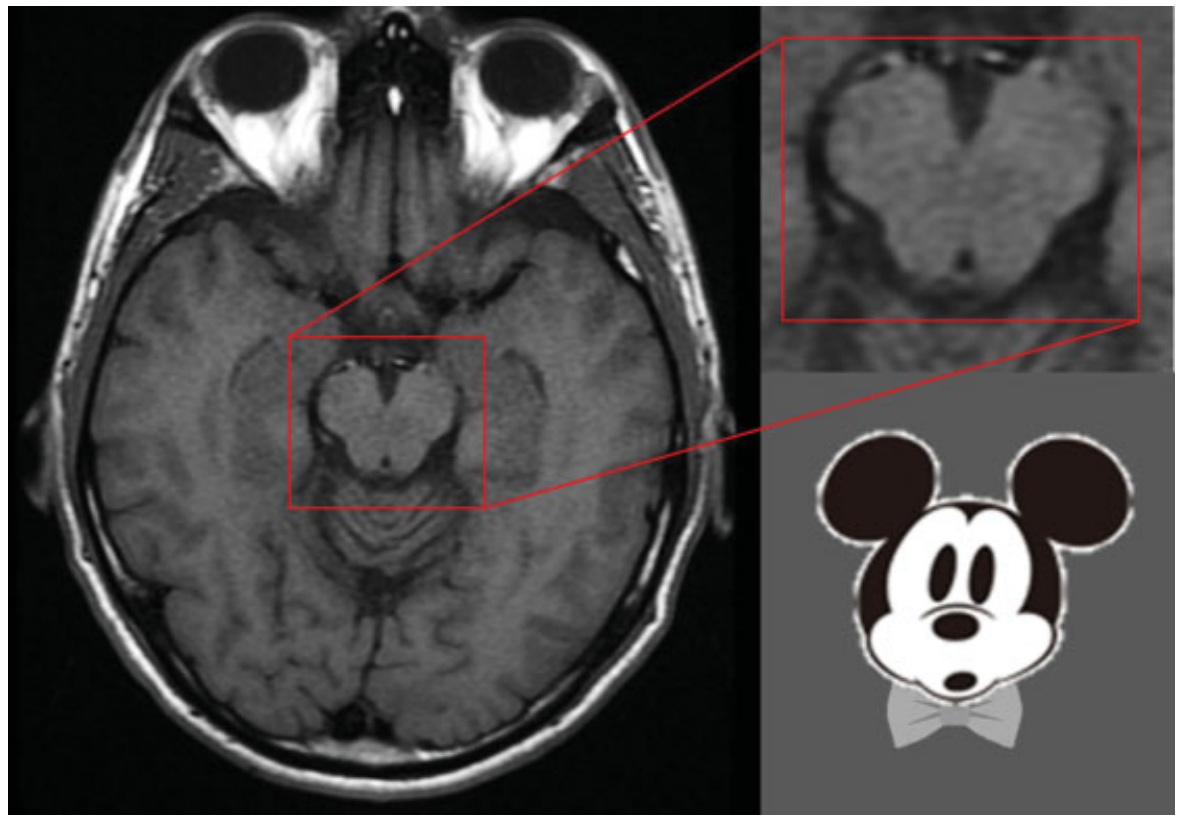

Fig. 1 Resonancia magnética ponderada en T1, en corte axial, en la que se compara el hallazgo con la cara de Mickey Mouse.

DOI https://doi.org/

10.1016/j.rard.2017.03.002.

ISSN 1852-9992.
Copyright (e) 2019, Sociedad Argentina de Radiología. Publicado por Thieme Revinter Publicações Ltda., Rio de Janeiro, Brazil. Todos los derechos reservados.

\section{License terms}

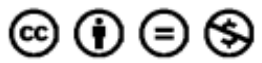

